\title{
STRATEGI PENGELOLAAN KOMPONEN PEMBELAJARAN BAHASA ARAB*
}

\author{
Fathur Rohman \\ Universitas Hasyim Asy'ari Jombang \\ email : mohalfath.mumtaz@gmail.com
}

\begin{abstract}
In the field of education, teaching management is one of the most important parts to ensure the success and the effectiveness of teaching. This article aims to describe the application of teaching management in the field of Arabic language teaching. The results presented in this article is that there are some aspects that need to manage in the field of teaching Arabic language, those are: curriculum, teaching materials, students, teachers, evaluation, teaching methods, and teaching purposes.
\end{abstract}

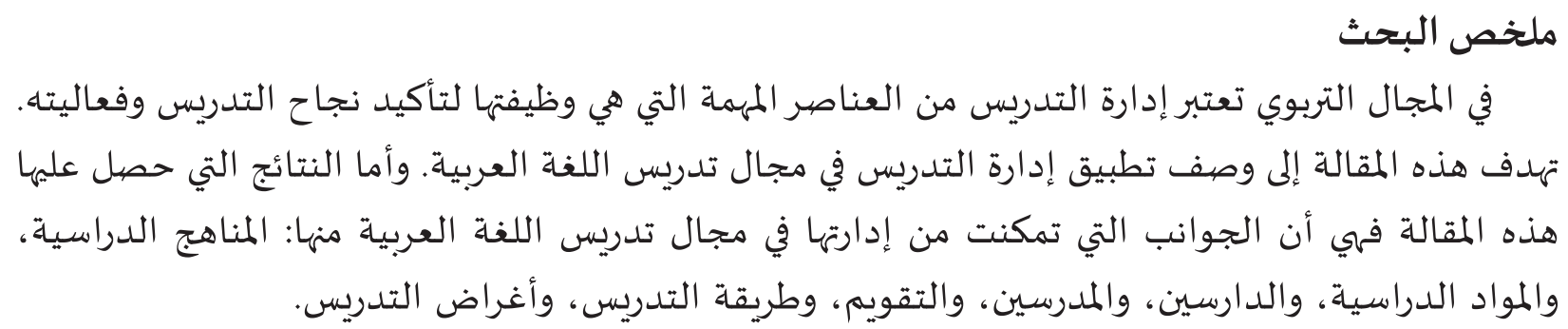

Kata Kunci: manajemen kelas, strategi guru, pembelajaran, bahasa Arab, komponen pembelajaran

\section{Pendahuluan}

Dalam wilayah pendidikan, manajemen merupakan salah satu faktor penting yang dapat menopang kesuksesan pembelajaran. Tujuan pembelajaran tidak dapat tercapai apabila rombongan belajar, media, materi ajar, sumber belajar, siswa yang belajar, dan lingkungan belajar tidak dikelola dengan baik. Evaluasi pembelajaran juga tidak akan terwujud tanpa pengelolaan atau manajemen yang baik. Karena itu, manajemen pembelajaran harus mampu menyelaraskan tujuan pembelajaran yang dirumuskan di dalam kurikulum atau perangkat pembelajaran sehingga menghasilkan kegiatan belajar mengajar yang memberdayakan potensi kognitif, afektif, dan psikomotorik.

Dalam kegiatan pembelajaran, guru bahasa Arabyang terampil sudah semestinya memahami tujuan pembelajaran, menguasai metode dan teknik pengajaran, menguasai materi pelajaran, mampu menggunakan media pembelajaran dengan efektif, serta mampu mengelola keragaman individu siswa di kelas dan mengevaluasi hasil belajar dengan baik. Masalah-masalah yang dihadapi oleh guru bahasa Arab dewasa ini tidak mungkin diselesaikan kecuali dengan perencanaan pembelajaran yang baik serta kepiawaian guru dalam mengelola dan melaksanakan pembelajaran 
sampai mengevaluasinya. Sebagian masalah pembelajaran bahasa Arab ada yang berkaitan dengan kemampuan guru dalam melaksanakan tugasnya secara profesional dan ada juga yang berkaitan dengan murid dalam pembelajaran.

Tulisan ini menawarkan gagasan tentang strategi pengelolaan pembelajaran bahasa Arab yang mencakup beberapa komponen, yaitu: kurikulum, tujuan, metode, materi, dan keragaman siswa. Dengan pengelolaan komponen tersebut, pembelajaran yang menyenangkan dan memberdayakan aspek-aspek kognitif, afektif, dan psikomotorik dapat diwujudkan dengan baik.

\section{Pengertian Manajemen}

Ada beberapa pengertian tentang manajemen. Menurut Suharsimi, dalam konteks pendidikan, manajemen didefinisikan sebagai suatu kegiatan kerjasama sekelompok manusia yang tergabung dalam organisasi pendidikan untuk mencapai tujuan pendidikan yang telah ditetapkan sebelumnya agar efektif dan efisien. ${ }^{1}$ Pengertian tersebut menjabarkan beberapa hal, yaitu:

1. Manajemen merupakan suatu proses sosial yang merupakan proses kerjasama antardua orang atau lebih secara formal.

2. Manajemen dilakukan dengan bantuan sumber-sumber,yakni:sumbermanusia, sumber material, sumber biaya, dan sumber informasi.

3. Manajemen dilakukan dengan metode kerja tertentu yang efisien dan efektif, dari segi tenaga, dana, waktu, dan sebagainya.

\footnotetext{
1 Suharsimi Arikunto, dan Lia Yuliana, Manajemen Pendidikan, (Yogyakarta: Aditya Media, 2008), h. 4.
}

4. Manajemen mengacu pada kepencapaian tertentu yang telah ditentukan sebelumnya. ${ }^{2}$

Manajemen merupakan suatu proses pengelolaan yang memiliki beberapa fungsi, di antaranya: 1) perencanaan; 2) pengorganisasian; 3) penggerakan; dan 4) pengawasan. Semua fungsi ini dilakukan untuk mencapai sasaran yang telah ditetapkan melalui pemanfaatan sumber daya manusia dan sumber daya lainnya.

\section{Manajemen Kurikulum}

Manajemen kurikulum adalah hal yang penting untuk memastikan kegiatan pembelajaran bisa berjalan dengan sukses. Ia merupakan proses yang membutuhkan perhatian semua pihak yang tergabung dalam organisasi sistem pendidikan. Terdapat perbedaan yang kompleks terkait komponen kurikulum, mulai dari tahapan pokok, tahapan kedua, dan tahapan berikutnya berupa serangkaian pekerjaan umum bidang pendidikan yang berkaitan dengan semua institusi pendidikan yang beroperasi. Kita harus siap menguji beberapa aspek kurikulum, pembelajaran, dan pengajaran untuk mendukung semua kegiatan pendidikan. ${ }^{3}$

Ada dua kunci pelaku manajemen pembelajaran dan pengajaran dalam kelas, yaitu siswa dan guru. Keduanya ditambah dengan satu atau beberapa staf pendukung kurikulum. Tiga anggota pengontrol kurikulum dalam pembelajaran ini akan menjadi guru kelas dan bertanggung jawab untuk

2 Oemar Hamalik, Manajemen Pengembangan Kurikulum, (Bandung: PT Remaja Rosdakarya, 2010), h. 16.

Ann RJ. Brigs and Daniel Sommefeldt, Managing Effective Learning dan Teaching (London: University of Leicester, 2002), h. 74. 
memelihara dan memastikan keberhasilan pembelajaran. ${ }^{4}$

Prinsip manajemen dalam kelas adalah guru bertanggung jawab penuh terhadap semua aspek perencanaan, pelaksanaan, dan evaluasi proses pembelajaran. Untuk memastikan proses ini berjalan, guru akan mendelegasikan beberapa tanggung jawab tersebut kepada siswa atau asisten di beberapa kelas. Di sekolah-sekolah dasar, ada tiga pihak yang berhubungan dan akan cenderung mendominasi di suatu kelas, tetapi di sekolah tingkat pendidikan lanjut, hubungan itu akan menjadi bagian tugas besar bagi beberapa kelas dan guru, sehingga mereka meningkatkan kegiatan pembelajaran untuk setiap siswa. Dalam situasi ini, dukungan staf harus menjadi jembatan penghubung, jika mereka dipekerjakan untuk mendukung siswa yang dikelompokkan. $^{5}$

\section{Pembelajaran Bahasa Arab}

Pembelajaran merupakan sebuah proses yang mecakup dua hal: seorang guru mengajarkan pengetahuan kepada anak didiknya dan usaha anak didik untuk mempelajari suatu pengetahuan. Dalam bahasa Inggris, "to teach" menunjuk arti: memperlihatkan sesuatu kepada seseorang melalui tanda atau simbol; penggunaan tanda atau simbol dengan maksud membangkitkan atau menumbuhkan respons mengenai kejadian, seseorang, observasi, penemuan, dan lain sebagainya. ${ }^{6}$ Dalam bahasa Arab, pengajaran atau pembelajaran diistilahkan dengan ta'lîm, masdar dari 'allama. Akar katanya, 'alima,

\footnotetext{
4 Ann RJ. Brigs and Daniel Sommefeldt, op. cit., h. 90

5 Ibid.

6 Wina Sanjaya, Kurikulum Pembelajaran (Jakarta: Prenada Media Group, 2008), h. 208
}

berarti "mengetahui" atau "mengerti". Ta'lîm berarti kegiatan yang menunjukkan pengetahuan yang sedang diajarkan di dalam kelas dengan menggunakan berbagai media pembelajaran. $^{8} \quad$ Pembelajaran diistilahkan juga dengan tadrîs, yang berasal dari "darasa", artinya: belajar atau mempelajari. ${ }^{9}$ Kata ini mengandung arti: proses interaksi antara lingkungan, hal-hal yang berkaitan dengan pembelajaran, dan respons siswa. ${ }^{10}$

Dalam bahasa Inggris, kata yang semakna dengan "pembelajaran" adalah learning atau training dan dalam bahasa Arab disebut juga darasa. Bagi Hilgard, belajar adalah proses perubahan melalui kegiatan atau prosedur latihan, baik di dalam laboratorium maupun dalam lingkungan alamiah. Belajar bukanlah sekadar mengumpulkan pengetahuan. Belajar adalah prosesmentalyangterjadidalam diri seseorang yang menyebabkan perubahan tingkah prilaku. Aktivitas mental itu terjadi karena adanya interaksi individu dengan lingkungan yang disadari. Proses belajar hakikatnya merupakan kegiatan mental yang tidak dapat dilihat. Artinya, proses perubahan yang terjadi dalam diri seseorang yang belajar tidak dapat kita saksikan. Kita hanya dapat menyaksikan gejala-gejala perubahan perilaku yang tampak. Dari sini dapat disimpulkan bahwa belajar adalah suatu proses aktivitas mental seseorang dalam berinteraksi dengan lingkungannya sehingga menghasilkan perubahan tingkah laku yang positif baik,

\footnotetext{
7 Atabik Ali dan Zuhdi Muhdlor, Kamus Kontemporer Arab Indonesia (Yogyakarta: Multi Karya Grafika, 1998), h.1313

8 'Abd al-Hafizh Muhammad Salamah, Tashmîm al-Tadrîs (Riyadh: Dâr al-Khariji, 2003), h. 15

9 Atabik Ali dan Zuhdi Muhdlor, op. cit., h. 890.

10 'Abd al-Hafizh Muhammad Salamah, op. cit., h. 16
} 
dalam aspek pengetahuan, sikap, maupun psikomotor. $^{11}$

Walaupun kita tidak dapat melihat proses terjadinya perubahan tingkah laku pada diri setiap orang, sebenarnya kita dapat menentukan apakah seseorang telah belajar atau belum dengan membandingkan kondisi sebelum dan sesudah proses pembelajaran berlangsung, ${ }^{12}$ seperti pada bagan berikut.

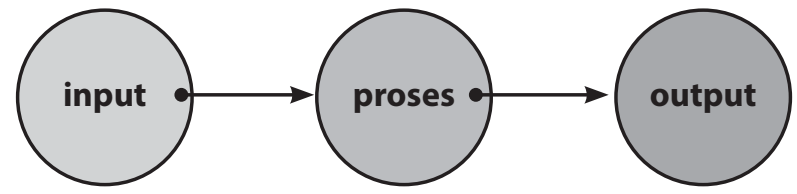

Input adalah siswa yang belum mendapatkan proses pembelajaran. Proses adalah sebuah kegiatan pembelajaran yang mencakup tujuan, isi/materi pembelajaran, metode, dan evaluasi pembelajaran. Output adalah keadaan siswa setelah memperoleh proses pembelajaran.

Bahasa Arab adalah bahasa yang digunakan oleh bangsa-bangsa Arab dan masyarakat Islam. Ia merupakan life language yang kuat, mengalami perkembangan, dan mampu menerjemahkan bahasa Prancis, India, Yunani, dan sebagainya. Bahasa Arab di abad pertengahan meruapakan sarana pengembangan ilmu pengetahuan dan penyebaran kebudayaan ke negaranegara Eropa. Kebudayaan Arab saat ini lebih bersinar daripada peradaban Eropa. Dan, bahasa Arab mampu menghilangkan kebodohan dan memotivasi dunia Islam untuk berkembang dan bangkit. ${ }^{13}$

Pada masa modern, ada faktor-faktor yang menyebabkan bahasa Arab dapat berkembang pesat, misalnya perkembangan dunia jurnalistik dan penyebarluasan

11 Wina Sanjaya, op. cit., h. 229.

12 Ibid., h. 203.

13 'Abd al-'Alim Ibrahim, al-Muwajjih al-Fannî li Mudarrisî al-Lughah al-'Arabiyyah (Kairo: Dâr alMa'arif, tt.), h. 48. pendidikan Islam. Saat ini, para akademisi bahasa Arab berusaha keras memopulerkan bahasa Arab sebagai bahasa resmi di negaranegara Arab dan sebagai alat komunikasi antarbangsa Arab. Ia juga dijadikan bahasa pengantar di berbagai sekolah, lembagalembaga pendidikan, dan perguruan tinggi, serta menjadi bahasa pers, penyiaran, pemerintahan, dan penyusunan karyakarya di negara-negara Arab. ${ }^{14}$

Dalam kenyataannya, tidak ada seorang pun yang mengingkari tentang eksistensi bahasa Arab sebagai bahasa yang layak untuk dipelajari. Irving mengatakan: kelayakan bahasa Arab itu karena bahasa Arab mem ilki metode isytiqâq dalam penurunan kosakatanya sehingga mampu menyusun kata-kata baru. Kekayaan kosakata bahasa Arab dibentuk melalui akar kata, lalu akar kata itu diungkapkan dengan berbagai macam bentuk lain yang memiliki arti yang berbeda-beda. Di antara keistimewaan bahasa Arab adalah perubahan kosakatanya tidak dapat dibatasi sehingga bahasa Arab memiliki kosakata yang sangat luas. Inilah yang menjadikan bahasa Arab sangat layak untuk dipelajari. Dan, bahasa Arab merupakan salah satu bahasa klasik terbesar seperti bahasa Yunani dan Sangsekerta. ${ }^{15}$

Dalam pembelajaran bahasa Arab, terdapat beberapa komponen, yaitu: tujuan pembelajaran, materi/isi pembelajaran, metode pembelajaran, evaluasi pembelajaran, siswa, dan guru. Dua komponen yang menjalankan proses pembelajaran bahasa Arab adalah siswa dan guru. Komponen pembelajaran bahasa Arab yang membutuhkan kemampuan manajerial atau pengelolaan adalah:

14 Ibid.

15 Rusydi Ahmad Thu'aimah, Ta'lîm al'Arabiyyah li Ghair al-Nâthiqîn bihâ (Mesir: Jâmi'ah al-Manshûrah), h. 31 
tujuan, materi, metode, dan evaluasi pembelajaran.

\section{Tujuan pembelajaran bahasa Arab}

Tujuan pembelajaran bahasa Arab bukan untuk memberantas buta huruf dan menggiatkan literasi. Tujuan pembelajaran bahasa Arab adalah membekali para pebelajar agar mampu membaca dan menulis dalam bahasa Arab sehingga mereka mengerti sejarah, masa depan, dan dapat memetik pelajaran dari generasi sebelumnya. Secara umum, tujuannya adalah membekali pebelajar menguasai empat keterampilan berbahasa, yaitu: menyimak, berbicara, membaca, dan menulis. Cara mengungkapkan bahasa Arab bisa dengan ucapan atau tulisan yang merupakan hasil dari kemampuan berbicara dan menulis seseorang. Adapun tujuan utama pembelajaran bahasa Arab di Madrasah Aliyah adalah siswa mampu mengungkapkan pikirannya dengan bahasa Arab, sebagai satu-satunya sarana siswa ketika ingin berkomunikasi dengan masyarakat, baik dengan cara berbicara atau menulis. ${ }^{16}$

Agar dapat menguasai bahasa Arab, diperlukan banyak cara, antara lain, latihan berbicara dan menulis dengan menggunakan bahasa Arab. Dalam latihan ini, siswa hendaknya mempelajari kaidah bahasa Arab yang diperlukan dari ilmu nahwu, sharf, dan balâghah. Pada saat latihan, guru harus sering mengaitkan (mengingatkan) tujuan pembelajaran bahasa Arab dengan konteks materi yang diajarkan. Selain itu, guru selazimnya menguasai cabangcabang ilmu bahasa Arab yang lain, seperti cara mengungkapkan bahasa Arab dengan

16 Jawdat al-Rukabi, Thuruq Tadrîs al-Lughah al'Arabiyyah (Damaskus: Dâr al-Fikr, 1996), h. 22-23. benar, membacanya yang benar, dan memahaminya. ${ }^{17}$

Dengan demikian, tujuan utama pembelajaran bahasa Arab adalah mampu mengungkapkan dengan bahasa Arab yang benar. Siswa harus dapat mengungkapkan keinginannya atau apa yang terlintas dalam pikirannya dengan sempurna dan benar, baik secara lisan atau tulisan. Siswa mampu memahami apa yang dia baca atau dengarkan, dan dia bisa ikut serta dalam berpikir sesuai dengan kamampuannya, usianya, dan kegemarannya. ${ }^{18}$

Adapun pengelolaan tujuan pembelajaran bahasa Arab dapat diperinci sebagai berikut:

1. Memberi pemahaman kepada siswa, khususnya siswa tingkat aliyah, bahwa bahasa adalah ungkapan makna dan pikiran; kata-kata tidak memiliki arti apa-apa kecuali jika memiliki tujuan. Pembelajaran bahasa Arab sangat efektif untuk mengembangkan kemampuan berpikir dan berkreasi dalam diri siswa.

2. Siswa dapat membaca teks dengan kecepatan yang disesuaikan dan dapat memahaminya dengan benar, dapat membedakan antara pokok pikiran utama (kalimat utama) dan kalimat tambahan, mampu mengembangkan kemampuan membacanya di tingkat Aliyah, dan mampu memberikan kritik terhadap apa yang dibaca, dan bisa mengambil pelajaran dari apa yang dia baca untuk diterapkan dalam kehidupannya.

3. Mampu mengembangkan kemampuan siswa untuk menyimak apa yang dia dengar dan mampu memahaminya secara benar dan luas, serta mampu

17 Jawdat al-Rukâbî, ibid., h. 23.

18 Ibid. 
memberikan kritik jika materi yang didengarnya itu tidak sesuai dengan tingkat pendidikan yang dia jalani.

4. Mampu mengembangkan kegemaran siswa untuk membaca dan menikmati apa yang mereka baca dengan memotivasinya untuk membaca kitabkitab yang disenaginya, khususnya di waktu luang.

5. Siswa mampu memahami teks-teks sastra, menemukan keindahan sastranya, menikmatinya, menganalisanya, dan mengkritiknya.

6. Siswa mampu memilih bacaan yang baik.

7. Siswa mampu menyimpulkan kaidahkaidah dasar bahasa Arab yang ada dalam bahasa dan tulisan, serta banyak melakukan latihan.

8. Siswa mampu menggunakan kamus dan mampu menyelesaikan beberapa pertanyaan, serta mampu menggunakan beberapa buku referensi Arab.

9. Siswa mampu memahami arti sebuah kalimat ketika membaca al-Qur'an dan ketika melantunkan sebuah syair.

10. Menumbuhkan keterampilan dan kemampuan siswa dalam berdiskusi, mengungkapkan pikirannya, pendapatnya, mengutarakan keinginannya, berpidato, dan menulis makalah.

11. Menjadikan siswa mampu mengungkapkan pengalamannya dan pendapatnya dalam bentuk tulisan yang menggunakan gaya bahasa yang benar, mengungkapkan fikirannya dengan benar dan teratur, serta memperhatikan pengunaan kaidah nomerik, membaginya menjadi beberapa paragraf, dan memperhatikan pengunaan catatan kaki.
12. Siswa mampu menulis dengan khat (tulisan) yang jelas dan rapi, sedangkan guru harus mampu mengembangkan bakat-bakat khusus siswa.

13. Siswa mampu berkomunikasi dengan teks-teks sastra dari berbagai macam masa yang berbeda.

Pembelajaran bahasa Arab mampu menunjukkan bakat-bakat khusus siswa yang berbeda-beda, khususnya dalam aspek sastra. $^{19}$

\section{Strategi Pengelolaan Tujuan Pembelajaran Bahasa Arab}

Di antara masalah pengelolaan tujuan pembelajaran bahasa Arab adalah perencanaan organisasi materi pembelajaran yang tidak teratur atau sistematis. Perencanaan yang tidak sistematis dapat menghambat pencapaian tujuan pembelajaran yang direncanakan. Padahal, keteraturan tema/topik yang diajarkan guru akan membantu pencapaian tujuan pembelajaran bahasa Arab. Sebab, setiap tema atau materi pembelajaran bertujuan untuk mendukung tujuan pembelajaran bahasa Arab.

Untuk mengatur tema-tema pembelajaran, sebaiknya guru menggunakan kaidah bahasa untuk mengevaluasi pembelajaran menulis dan berbicara, kaidah penulisan untuk membenarkan kesalahan penulisan, serta kaidah qirâ'ah dan kitâbah untuk membantu mengungkapkan pikiran dan komunikasi berbahasa. Guru hendaknya memahami bahwa tujuan mempelajari bahasa itu bukan untuk menguasai kaidah tata bahasa (qawâ'id). Sayangnya, kita sering melihat sebagian guru yang berusaha mengubah pembelajaran teks-teks Arab

19 Jawdat al-Rukâbî, ibid., h. 75-76. 
menjadi pelajaran qawâ'id, padahal hal itu bisa menjadikan siswa enggan dan malas belajar. ${ }^{20}$

Agar tujuan pembelajaran bahasa Arab bisa tercapai dan dapat direalisasikan dalam pembelajaran, baik oleh guru atau oleh siswa, maka penyusunan tujuan pembelajaran bahasa Arab harus mengikuti sistem pengelolaan tujuan yang baik.

Pengelolaan tujuan pembelajaran bahasa Arab dapat dilakukan dengan beberapa cara, di antaranya:

1. Harus membatasi tujuan-tujuan operasional yang sifatnya umum di setiap materi pembelajaran.

2. Setiap tema pembelajaran dibatasi dengan tujuan pembelajaran.

3. Memberi keterangan bahwa tujuan pembelajaran itu bisa membantu kesuksesan proses pembelajaran bahasa dalam memilih isi materi, soal, dan metode pembelajaran.

4. Penjelasan dalam tujuan operasional pembelajaran dapat memotivasi guru dan siswa untuk mencapai tujuan pembelajaran bahasa tersebut. ${ }^{21}$

\section{Materi Pembelajaran Bahasa Arab}

Materi pembelajaran bahasa Arab tidak hanya terdiri dari sekumpulan pengetahuan atau kumpulan informasi, tetapi harus merupakan kesatuan pengetahuan terpilih dan dibutuhkan, baik bagi pengetahuan itu sendiri maupun bagi siswa dan lingkungannya. ${ }^{22}$ Materi pembelajaran

\footnotetext{
20 Mahmud Ahmad Sayyid, Fî Tharâ'iq Tadrîs al-Lughah al-'Arabiyyah (Damaskus: tp., 1997), h. 736-737.

21 Ibid., h. 737.

22 NanaSyaodihSukmadinata,Pengembangan Kurikulum (Bandung: PT Rosda Karya, 2006), h. 127.
}

dalam pendidikan modern meliputi tigajenis materi, yaitu ilmu pengetahuan (kognitif), keterampilan (psikomotorik), dan niali-nilai (afektif). ${ }^{23}$

Materi pembelajaran bahasa Arab dapat dibagi menjadi dua kelompok tingkatan siswa, yaitu siswa pemula dan siswa lanjutan. Materi untuk kelompok siswa pemula memiliki pengertian sebagai berikut:

1. Buku yang ditujukan untuk siswa pemula di setiap kelasyang mengandung pelajaran empat keterampilan, yaitu menyimak, berbicara, membaca, dan menulis. Teks utama menjadi bahasan yang dipelajari, isinya memuat berbagai macam keterampilan berbahasa serta kebudayaan.

2. Buku latihan yang digunakan siswa untuk mengerjakan tugas-tugas bahasa Arab.

3. Buku pedoman guru di setiap kelas yang berisi cara menyampaikan materi pelajaran, tujuan-tujuan pembelajaran, keterampilan berbahasa, dan kebudayaan yang dapat dikembangkan oleh siswa di setiap kelas, serta cara berinteraksi dengan buku ajar. Buku ini bisa juga memuat beberapa pembelajaran bahasa di kelas yang harus dilakukan untuk mencapai tujuan kurikulum. ${ }^{24}$

Materi pelajaran bahasa Arab untuk siswa tingkat lanjut memiliki pengertian sebagai berikut:

1. Buku bacaan, buku sastra, dan teks-teks Arab yang dipelajari oleh siswa.

23 Hanun Asrohah dan Anas Amin Alamsyah, Pengembangan Kurikulum (Surabaya: Kopertais wilayah IV, 2010), h. 112.

24 Rusydi Ahmad Thu'aimah, Manâhij Tadrîs al-Lughah al-'Arabiyyah bi al-Ta'lîm al-Asâsî, (Kairo: Dar al-Fikr al-'Arabi, tt.), h. 55-56. 
2. Buku untuk latihan berbahasa Arab yang dipelajari oleh siswa di berbagai kelas dan mengajarkan tentang kaidah nahwu, sharaf, imla' dank khat.

3. Buku yang memiliki judul tertentu, yang melatih siswa untuk memperoleh pengetahuan, dan siswa merasa senang ketika membacanya.

4. Buku pedoman guru di berbagai kelas yang memberi pengetahuan guru tentang cara menggunakan buku-buku pelajaran berbahasa Arab. ${ }^{25}$

\section{Strategi Pengelolaan Materi Pembelajaran Bahasa Arab}

Di antara problem pengelolaan materi pembelajaran adalah pada prioritas materi atau keterampilan bahasa yang akan diajarkan. Ada yang memprioritaskan aspek menyimak dan berbicara, dan ada pula yang mengutamakan aspek menulis dan membaca. Guru yang mengutamakan aspek menulis akan membatasi materi muhâdatsah (percakapan) sehingga siswa jarang berlatih berbicara dalam bahasa Arab dan tidak terbiasa menyimak ungkapan bahasa Arab. Bahkan, guru kadang mengubah pembelajaran qirâ'ah (membaca) menjadi pembelajaran menulis atau mengerjakan soal-soal bahasa Arab. ${ }^{26}$ Selain itu, guru bahasa Arab juga sering mengajari siswa tingkat dasar (ibtidâ'î) menulis huruf-huruf dan kalimat-kalimat bahasa Arab sejak awal masuk sekolah. Hal ini menjadikan siswa merasa sulit dan frustrasi dalam mempelajari bahasa Arab karena belum mampu menulis karakter huruf Arab yang rumit, terutama ketika disambung atau diputus. $^{27}$

\footnotetext{
25 Rusydi Ahmad Thu'aimah, ibid., h. 56.

26 Mahmud Ahmad Sayyid, op. cit., h. 736.

27 Ibid.
}

Fenomena di atas menunjukkan pentingnya memahami pengelolaan organisasi materi pembelajaran bahasa Arab agar tidak membuat siswa frustrasi. Langkah-langkah pengelolaan materi pembelajaran bahasa Arab adalah sebagai berikut:

1. Menyiapkan rencana pembelajaran untuk suatu program jurusan.

2. Menyiapkan rencana kurikulum materi (buku ajar) dan unsur-unsur yang pokok (yang akan dibahas).

3. Menyusun prinsip-prinsip penyusunan materi yang disetujui oleh dewan penasihat atau panitia program.

4. Menyiapkan struktur materi pembelajaran dalam bentuk cetak dan menyusunnya dalam bentuk buku ajar.

5. Mengevaluasi kandungan materi kebahasaan yang akan ditulis dalam buku ajar.

6. Mendesain proses pembelajaran dan syarat-syarat yang harus dipenuhi dalam pembelajaran.

7. Menulis aspek-aspek keterampilan bahasa dan kebahasan yang dimuat dalam materi.

8. Membuat desain yang menarik pada layout isi buku dan mencetaknya.

9. Meneliti hasil cetakan dan melengkapinya dengan sampul yang menarik. ${ }^{28}$

\section{Metode Pembelajaran}

\section{Bahasa Arab}

Metode dalam bahasa Arab disebut tharîqah, pendekatan disebut madkhal, dan teknik disebut uslûb. Ketiga istilah

28 Yusri al-Mihdawi, Intâj al-Mawâdd alTa'lîmiyyah li Barâmij al-Ta'lîm 'an Bu'd (al-Mamlakah al-Maghribiyah, 2000), h. 130-131. 
ini memiliki persamaan dan kemiripan arti sehingga banyak buku pembelajaran bahasa Arab menyamakan ketiganya dalam penggunaannya, tetapi ada juga yang membedakan pengertiannya.

Edward Antony (1963) menjelaskan konsep ketiga istilah tersebut sebagai berikut. Pendekatan adalah seperangkat asumsi berkenaan dengan hakikat bahasa danbelajar-mengajarbahasa. Metodeadalah rencana menyeluruh penyajian bahasa secara sistematis berdasarkan pendekatan yang ditentukan. Sedangkan, teknik adalah kegiatan spesifik yang diimplementasikan dalam kelas, selaras dengan metode dan pendekatan yang telah dipilih. Dengan demikian, pendekatan bersifat aksiomatis, metode bersifat prosedural, dan teknik bersifat operasional. ${ }^{29}$

Menurut Nana Sudjana, metode mengajar adalah cara yang digunakan oleh guru dalam mengadakan hubungan dengan siswa pada saat berlangsungnya pengajaran. Dalam pengertian lain, metode mengajar merupakan cara-cara yang digunakan guru untuk menyampaikan bahan pelajaran kepada siswa untuk mencapai tujuan. Dalam kegiatan mengajar, makin tepat metode yang digunakan maka makin efektif dan efisien kegiatan belajar mengajar yang dilakukan oleh guru dan siswa, yang pada akhirnya akan menunjang dan mengantarkan keberhasilan belajar siswa dan keberhasilan mengajar yang dilakukan oleh guru. Sebab, guru harus dapat memilih dengan tepat metode apa yang akan digunakan dalam mengajar dengan melihat tujuan belajar yang hendak dicapai, situasi, dan kondisi, serta tingkat perkembangan siswa. ${ }^{30}$

29 Ahmad Fuad Efendi, Metodologi Pembelajaran Bahassa Arab (Malang: Misykat, 2005), h. 6.

30 Dalam Darwyn Syah, Perencanaan Sistem Pengajaran Pendidikan Agama Islam (Jakarta: Gaung Persada Pers, 2007), h. 133.
Penggunaan dan pemilihan metode oleh guru bahasa Arab sangat mempengaruhi proses dan hasil pembelajaran bahasa Arab yang mencakup empat keterampilan berbahasa, yaitu istimâ' (menyimak), kalâm (berbicara), qirâ'ah (membaca), dan kitâbah (menulis). Karena itu, seorang guru dituntut untuk menguasai banyak metode pembelajaran bahasa Arab. Di antara metode pembelajaran bahasa Arab adalah metode nahwu wa tarjamah, mubâsyirah, sam'iyyah syafahiyyah, îhâ'iyyah, shâmitah, istijâbah al-jasadiyyah al-kâmilah, ittishâliyyah, dan lain sebagainya.

Dengan menguasai berbagai macam metode tersebut, guru dapat melaksanakan pembelajaran bahasa Arab dengan baik, dinamis, menyenangkan, dan memberdayakan.

\section{Strategi Pengelolaan Metode Pembelajaran Bahasa Arab}

Kebanyakan guru bahasa Arab masih mengajar dengan menggunakan metode ceramah. Hasilnya, siswa lebih banyak memahami ilmu kebahasaan tetapi kurang terlatih pada keterampilan bahasa. Sedangkan, pengetahuan kebahasaan akan cepat dilupakan apabila tidak ada interaksi dengan pikiran dan tanpa pelatihan. ${ }^{31}$ Guru bahasa Arab juga sering kali menggunakan model pembelajaran yang monoton, padahal materi yang diajarkan tidak sama dan lebih menuntut pada keterampilan berbahasa. Guru juga terkadang mengabaikan tahapan-tahapan yang benar dalam pembelajaran bahasa Arab, sehingga pembelajarannya tidak konstruktif.

Pembelajaran model demikian tentunya bertentangan dengan tuntutan zaman

31 Mahmud Ahmad Sayyid, loc. cit. 
sekarang. Guru-guru di negara-negara berkembang seharusnya menciptakan situasi belajar positif yang melibatkan siswa aktif dalam menemukan pengetahuan secara efektif dan membatasi peran guru dalam pengawasan dan evaluasi. ${ }^{32}$

Kemampuan pengelolaan pembelajaran bahasa Arab sangat dibutuhkan oleh guru ketika mengajar bahasa Arab. Ia menjadi kunci kesuksesan proses pembelajaran bahasa Arab. Dan, pencapaian tujuan pembelajaran bahasa Arab sangat ditentukan oleh metode pembelajarannya.

Seorang guru harus dapat mengelola proses pembelajaran bahasa Arab dalam hal memilih metode, menerapkan metode, mengelola kelas, dan menggunakan media pembelajaran. Sebuah metode dianggap berhasil apabila aplikasinya memenuhi beberapa persyaratan berikut:

1. Metode harus sesuai dengan kondisi siswa, tingkat pertumbuhan akalnya, aspek-aspek sosial dan ekonominya, serta lingkungan keluarganya.

2. Metode harus mengikuti prinsip pembelajaran secara bertahap, seperti dari yang mudah ke yang sulit, dari yang sederhana ke yang kompleks, dari yang jelas ke yang abstrak, dan dari yang hissi (indrawi) ke yang masuk akal, sehingga dapat digunakan guru dalam membimbing pembelajaran.

3. Metode harus mampu mengakomodir semua perbedaan individual siswa di kelas, keragaman perilakunya, kecerdasan IQ-nya, dan kekuatan fisiknya. Terhadap perbedaan tersebut, guru bahasa Arab harus mampu mengatasinya. ${ }^{33}$

32 Ibid.

33 Muhammad 'Abd al-Qadir Ahmad, Thuruq Ta'lîm al-Lughah al-'Arabiyyah (Kairo: Maktabah al-
Dengan demikian, strategi pengelolaan metode pembelajaran bahasa Arab adalah dengan cara menguasai berbagai metode yang sesuai dengan karakter keragaman siswa di kelas serta sesuai dengan materi dan keterampilan bahasa Arab yang diajarkan.

\section{Evaluasi Pembelajaran \\ Bahasa Arab}

Evaluasi berasal dari kata evaluation (Inggris). Kata ini diserap dalam perbendaharaan bahasa Indonesia dengan tujuan mempertahankan kata aslinya dengan sedikit penyesuaian pelafalan menjadi "evaluasi". Arti evaluasi adalah suatu upaya untuk menentukan nilai atau jumlah. Evaluasi dapat didefinisikan sebagai kegiatan untuk mengumpulkan informasi tentang hasil pekerjaan tertentu, yang selanjutnya informasi tersebut digunakan untuk menentukan alternatif yang tepat dalam mengambil sebuah keputusan. ${ }^{34}$

Guru adalah seorang evaluator kurikulum, sehingga dia harus melakukan pertimbangan penting, yaitu evaluasi formatif untuk perbaikan program, dan evaluasi sumatif untuk memutuskan kelanjutan program yang dievaluasi, atau menghentikannya dengan program lain. Model-model evaluasi yang dapat dipilih dan diaplikasikan adalah model pencapaian tujuan, model pertimbangan, model pengambilan keputusan dan model deskriptif. $^{35}$

Nahdhah, 1979), h. 8.

34 Suharsimi Arikunto, Evaluasi Program Pendidikan (Jakarta: Bumi Aksara, 2010), h. 1-2.

35 Oemar Hamalik, Dasar-dasar Pengembangan Kurikulum (Bandung: Rosda Karya, 2009), h. 191. 
Evaluasi dalam pembelajaran bahasa Arab memiliki berbagai macam kegunaan, antara lain: ${ }^{36}$

1. Evaluasi mengarahkan siswa pada semangat belajar. Siswa akan belajar rajin ketika hendak ujian. Berbagai macam ulangan dapat direspons positif oleh siswa dengan berbagai cara belajar. Evaluasi juga bisa menjadi sarana yang baik agar guru dan siswa lebih memperhatikan tujuan pembelajaran yang sudah ditentukan.

2. Evaluasi menjadikan guru lebih bersungguh-sungguh dalam mengajar. Sebab, guru biasanya mengajar dengan menggunakan strategi yang sesuai dengan soal-soal ujian. Itu artinya, ulangan-ulangan bisa memperkuat hafalan (pemahaman) siswa karena strategi yang digunakan guru dalam mengajar sesuai dengan tujuan pembelajaran.

3. Evaluasi menjadi sarana efektif untuk memberikan umpan balik karena materi pelajaran mengarah pada evaluasi yang membantu identifikasi pencapaian tujuan pembelajaran.

4. Evaluasi dapat memberikan laporan hasil pembelajaran, seperti penerimaan siswa di sekolah, pembatasan penetapan siswa, jenis jurusan yang akan diambil, dan kenaikan kelas. ${ }^{37}$

Dari berbagai macam kegunaan evaluasi pembelajaran bahasa Arab di atas, dapat disimpulkan bahwa tujuan utama evaluasi adalah untuk mengukur ketercapaian pembelajaran bahasa Arab.

36 Uril Bahruddin, Mahârah al-Tadrîs (Malang: UIN Press, 2011), h. 198

37 Ibid.

\section{Strategi Pengelolaan Evaluasi Pembelajaran Bahasa Arab}

Evaluasi yang objektif seharusnya bisa mengukur sejauh mana guru dapat merealisasikan tujuan-tujuan pembelajaran. ${ }^{38}$ Namun, guru bahasa Arab sering kali menggunakan soal-soal tes pencapaian hasil belajar hanya untuk mengukur keterserapan materi pembelajaran, tidak sampai pada kemampuan berbahasa Arab. Padahal, kemampuan berbahasa merupakan bagian penting tujuan belajar bahasa. Selain itu, terdapat kerancuan antara materi yang diberikan dengan tes untuk mengevaluasi hasil belajar. Akibatnya, sering dijumpai bahwa tes bahasa Arab lebih mengedepankan penguasaan tatabahasa dan unsurunsur bahasa, seperti kosakata dan struktur kalimat. ${ }^{39}$

Fenomena di atas disebabkan oleh ketidakmampuan guru dalam membuat tes bahasa Arab terstandar yang mampu mengukur kemampuan berbahasa siswanya. Oleh karena itu, hal mendasar yang perlu diperbaiki adalah mengubah paradigma belajar bahasa Arab dari semata-mata menguasai ilmu bahasa Arab menjadi terampil menggunakan bahasa Arab sebagai alat komunikasi, baik secara lisan maupun tulis. $^{40}$

Selanjutnya, ulangan-ulangan yang disusun harus mampu mengevaluasi seluruh bidang keterampilan bahasa, seperti menyimak dan bercakap, di samping mengetes kemampuan imlâ' (dikte), qawâ'id (kaidah bahasa), dan mufradât. Namun, untuk siswa tingkat pertama, sebaiknya ulangan dilakukan untuk mengukur kemampuan menghafal mufradâtdan kaidah

38 Mahmud Ahmad Sayyid, op. cit., h. 737.

39 Acep Hermawan, Metodologi Pembelajaran Bahasa Arab (Bandung: Rosda, 2011), h. 284.

$40 \quad$ Ibid., h. 283. 
bahasa, bukan mengukur pemahaman yang bersifat analisis kritis dan kemampuan berinteraksi. ${ }^{41}$

Ada beberapa langkah yang harus dilalui dalam mengembangkan sebuah tes, yaitu:

1. Menganalisis standar kompetensi (SK) dan kompetensi dasar (KD).

2. Menyusun peta konsep utama berdasarkan SK dan KD yang diperlukan untuk mengelompokkan kompetensi esensial dan level pemahaman.

3. Menyusun matriks rancangan tes atau kisi-kisi tes.

4. Memilah peta konsep berdasarkan indikator yang ingin dikembangkan menjadi item tes.

5. Menyusun spesifikasi untuk satu atau lebih butir soal.

6. Menulis butir soal berdasarkan spesifikasi butir soal yang telah dikembangkan.

7. Menentukan rubrik soal berdasarkan spesifikasi butir soal yang telah dikembangkan.

8. Menentukan rubrik atau pedoman penskoran. ${ }^{42}$

\section{Siswa dan Guru dalam \\ Pembelajaran Bahasa Arab}

Dalam bahasa Arab, kata yang merujuk makna siswa adalah tilmîdz (jamak: talâmîdz) yang artinya murid yang belajar (diajar) dan thâlib (jamak: thullâb) yang artinya pencari (ilmu). Kata pertama digunakan untuk tingkat dasar, sedangkan kata kedua digunakan untuk tingkat menengah dan perguruan tinggi. Karakteristik siswa atau peserta didik adalah orang yang belum dewasa dan

41 Mahmud Ahmad Sayyid, op. cit., h. 737

42 Acep Hermawan, op. cit., h. 280. memiliki sejumlah potensi dasar yang masih perlu dikembangkan.

Guru adalah pendidik profesional dengan tugas utama mendidik, mengajar, membimbing, mengarahkan, melatih, menilai, dan mengevaluasi perserta didik pada jalur pendidikan formal. Tugas utama guru akan efektif jika ia memiliki tingkat profesionalitas tertentu yang tercermin dari kompetensi, kemahiran, kecakapan, atau keterampilan yang memenuhi standar mutu atau norma etik tertentu. ${ }^{43}$

Ada beberapa sifat yang harus dimiliki oleh guru bahasa Arab, di antaranya adalah:

1. Menyukai materi yang diajarkan. Guru yang tidak menyukai pelajaran bahasa Arab tidak mampu menjadikan siswanya mencintai bahasa Arab.

2. Menguasai materi yang diajarkan. Guru bahasa Arab yang tidak menguasai materi bahasa Arab tidak bisa mengajar dengan langkah-langkah yang benar.

3. Guru bahasa Arab harus mampu berbicara fasih dalam bahasa Arab serta berperilaku yang baik. Berbicara bahasa Arab yang fasih adalah sarana utama untuk mengajarkan bahasa Arab. Dengan kefasihannya, guru dapat memotivasi siswanya untuk belajar bahasa Arab sehingga mereka dapat menguasai keterampilan berbahasa dan senang belajar bahasa Arab.

4. Guru bahasa Arab harus banyak menguasai kebudayaan dan sumbersumber belajar berbahasa Arab.

5. Guru merupakan sosok pembimbing. Selain mengajar di dalam kelas, guru bahasa Arab harus membimbing siswanya dengan menunjukkan sumber

43 Sudarwan Danin dan Khairil, Profesi Kependidikan (Bandung: Alfabeta, 2010), h. 5. 
belajar bahasa Arab atau mengadakan percakapan dengan bahasa Arab di luar kelas.

6. Guru bahasa Arab tidak boleh hanya mengajar tetapi harus memiliki karya sastrasecaraumum,sertasukamengikuti penyusunan buku ajar. Hasil karya sastra yang umum akan memperkaya pengetahuan kebudayaannya, dan penyusunan buku ajar akan menambah kemampuan mengajarnya serta pengalaman untuk memperbaiki pores pembelajaran bahasa Arab. ${ }^{44}$

\section{Strategi Pengelolaan Siswa dan Guru}

Siswa dalam suatu kelas biasanya memiliki kemampuan yang beragam: pandai, sedang, dan kurang. Karena itu, guru harus mengatur kapan siswa bekerja perorangan, berpasangan, berkelompok, atau klasikal. Jika berkelompok, kapan siswa dikelompokkan berdasarkan kemampuan sehingga ia dapat berkonsentrasi membantu yang kurang, dan kapan siswa dikelompokkan secara campuran sehingga terjadi tutor sebaya. Dalam hal ini, guru dapat mengatur dan merekayasa siswa berdasarkan situasi yang ada ketika proses belajar mengajar berlangsung. ${ }^{45}$

Keragaman siswa harus dipahami guru dalam mengatur strategi pengelolaan kelas, sehingga tidak ada satu siswa pun yang merasa tidak diperhatikan atau dirugikan dalam proses pembelajaran bahasa Arab. Perbedaan antara peserta didik mengharuskan layanan pendidikan yang berbeda terhadap mereka. Bila layanan

44 Jawdat al-Rukâbî, op. cit., h. 47-48.

45 Abdul Majid, Perencanaan Pembelajaran (Bandung: PT Remaja Rosdakarya, 2007), h. 112. secara individual dianggap kurang efisien, dilakukan pengelompokan berdasarkan persamaan dan perbedaan peserta didik, agar kekurangan pada pengajaran secara klasikal dapat dihindari. Dengan perkataan lain, pengelompokan adalah konvergensi dari pengajaran sistem klasikal dan sistem individual. Alasan pengelompokan peserta didik juga didasarkan atas realitas bahwa peserta didik secara terus menerus tumbuh dan berkembang. Di sini, pengelompokan dapat mengatasi kesenjangan tumbuhkembang keragaman peserta didik, sehingga peserta didik yang lamban tidak mengganggu yang cepat atau sebaliknya. ${ }^{46}$

Pengelompokan atau grouping didasarkan atas pandangan bahwa peserta didikmempunyai kesamaan dan perbedaan. Kesamaan peserta didik menempatkan mereka di kelompok yang sama, dan perbedaan mereka menempatkannya di kelompok yang berbeda. ${ }^{47}$

Mitchun (1960) mengemukakan dua jenis pengelompokan peserta didik. Pertama, ability grouping, yaitu pengelompokan berdasarkan kemampuan (kepandaian tertentu). Kedua, subgrouping with in the class, yaitu membagi kelompok besar menjadi kelompok kecil. ${ }^{48}$ Ability grouping berarti menggabungkan peserta didik yang pandai dengan yang pandai, yang kurang pandai dengan yang kurang pandai baik dalam satu kelas atau dalam beberapa kelas. Sub-grouping with the class berarti membagi beberapa kelompok kecil dari ability grouping atau berdasarkan kebutuhan tertentu.

Kelompok-kelompok kecil pada tiap kelas dapat dibentuk berdasarkan karakteristik individu berikut:

\footnotetext{
46 Ibid., h. 96

47 Ibid., h. 95

48 Ibid., h. 96
} 
1. Interest grouping, yaitu pengelompokan yang didasarkan atas minat peserta didik.

2. Special need grouping, yaitu pengelompokan berdasarkan kebutuhan/ keterampilan khusus.

3. Team grouping, yaitu suatu kelompok yang terbentuk karena dua atau lebih peserta didik yang ingin bekerja dan belajar bersama untuk memecahkan masalah khusus.

4. Tutorial grouping, yaitu pengelompokkan peserta didik bersama guru untuk merencanakan kegiatan-kegiatan kelompoknya.

5. Research grouping, yaitu pengelompokkan dua atau lebih peserta didik untuk menggarap suatu topik penelitian yang akan dilaporkan di depan kelas. $^{49}$

Selanjutnya, untuk mencapai tujuan pembelajaran bahasa Arab, guru harus bertindak sebagai manajer dalam kelas ketika proses pembelajaran. Ketika mengelola pembelajaran bahasa Arab, guru harus memperhatikan hal-hal berikut:

1. Karaktristik peserta didik

2. Kompetensi dasar yang diharapkan

3. Waktu yang tersedia

4. Sarana prasarana belajar

5. Kemampuan dan ketepatan memilih pendekatan, metode, dan teknik pembelajaran yang selaras dan serasi. ${ }^{50}$

Dengan memperhatikan hal-hal tersebut, seorang guru dapat melaksanakan pembelajaran bahasa Arab dengan baik dan mampu mencapai tujuan pembelajaran yang diharapkan.

49 Ibid., h. 98-100.

50 Iskandarwassid dan Dadang Sunendar, Strategi Pembelajaran Bahasa (Bandung: PT Remaja Rosdakarya, 2011), h. 174.

\section{Simpulan}

Masalah-masalah yang dihadapi oleh guru bahasa Arab dewasa ini tidak mungkin diselesaikan hanya dengan perencanaan pembelajaran yang baik, tetapi harus disertai dengan kepiawaian guru dalam melaksanakan dan mengelola pembelajaran. Pengelolaan atau manajemen pembelajaran diyakini dapat menyelesaikan masalah pembelajaran bahasa Arab, baik yang berkaitan dengan kemampuan guru dalam melaksanakan tugasnya secara profesional maupun yang berkaitan dengan keragaman individu siswa dalam belajar.

Strategi pengelolaan pembelajaran bahasa Arab mencakup beberapa komponen dalam pembelajaran, yaitu: kurikulum, tujuan, metode, materi, evaluasi, dan siswa. Pengelolaan komponen-komponen tersebut bertujuan untuk mewujudkan pembelajaran yang memberdayakan aspekaspek kognitif, afektif, dan psikomotorik. Pengelolaan pembelajaran bahasa Arab harus dipandang sebagai usaha mengelola semua komponen pembelajaran untuk mencapai tujuan pembelajaran bahasa Arab, yaitu membekali para pebelajar untuk menguasai empat keterampilan berbahasa: menyimak, berbicara, membaca, dan menulis dalam bahasa Arab. [] 


\section{Daftar Rujukan}

Abdul Majid, Perencanaan Pembelajaran, Bandung: PT Remaja Rosdakarya, 2007.

Ahmad, Muhammad 'Abd al-Qadir, Thuruq Tallim al-Lughah al-'Arabiyyah, Kairo: Maktabah alNahdhah, 1979.

Ali, Atabik dan Zuhdi Muhdlor, Kamus Kontemporer Arab Indonesia, Yogyakarta: Multi Karya Grafika, 1998.

Arikunto, Suharsimi, dan Lia Yuliana, Manajemen Pendidikan, Yogyakarta: Aditya Media, 2008.

Arikunto, Suharsimi, Evaluasi Program Pendidikan, Jakarta: Bumi Aksara, 2010.

Asrohah, Hanun, dan Anas Amin Alamsyah, Pengembangan Kurikulum, Surabaya: Kopertais wilayah IV, 2010

Bahruddin, Uril, Mahârah al-Tadrîs, Malang: UIN Press, 2011.

Brigs, Ann RJ. and Daniel Sommefeldt, Managing Effective Learning and Teaching, London: University of Leicester, 2002.

Danin, Sudarwan dan Khairil, Profesi Kependidikan, Bandung: Alfabeta, 2010.

Efendi, Ahmad Fuad, Metodologi Pembelajaran Bahassa Arab, Malang: Misykat, 2005.

Hamalik, Oemar, Dasar-dasar Pengembangan Kurikulum, Bandung: Rosda Karya, 2009.

—, Manajemen Pengembangan Kurikulum, Bandung: PT Remaja Rosdakarya, 2010.

Hermawan, Acep, Metodologi Pembelajaran Bahasa Arab, Bandung: Rosda, 2011.

Ibrahim, 'Abd al-'Alim, al-Muwajjih al-Fannîl li Mudarrisî al-Lughah al-'Arabiyyah, Mesir: Dar al-Ma'arif, $\mathrm{tt}$.

Iskandarwassid dan Dadang Sunendar, Strategi Pembelajaran Bahasa, Bandung: PT Remaja Rosdakarya, 2011.

al-Mihdawi, Yusri, Intâj al-Mawâd al-Ta'lîmiyyah li Barâmij al-Ta'lîm 'an Bu'd, al-Mamlakah alMaghribiyyah, 2000.

al-Rukabi, Jawdat, Thuruq Tadrîs al-Lughah al-'Arabiyyah, Damaskus: Dar al-Fikr, 1996.

Salamah, 'Abd al-ㅌafizh Muhammad, Tashmîm al-Tadrîs, Riyadh: Dar al-Khariji, 2003.

Sanjaya, Wina, Kurikulum Pembelajaran, Jakarta: Prenada Media Group, 2008

Sayyid, Mahmud Ahmad, Fî Tharâ'íq Tadrîs al-Lughah al-'Arabiyyah, Damaskus: tp., 1997

Sukmadinata, Nana Syaodih, Pengembangan Kurikulum, Bandung: PT Rosda Karya, 2006.

Syah, Darwin, Perencanaan Sistem Pengajaran Pendidikan Agama Islam, Jakarta: Gaung Persada Press, 2007.

Thu'aimah, Rusydi Ahmad, Manâhij Tadrîs al-Lughah al-'Arabiyyah bi al-Ta'lîm al-Asâsî, Kairo: Dar al-Fikr al-Arabi, tt.

— , Ta'lîm al-'Arabiyyah li Ghair al-Nâthiqîn bihâ, Mesir: Jami’ah al-Mansurah, tt. 
Arabiyât Jurnal Pendidikan Bahasa Arab dan Kebahasaaraban 